\title{
Pengembangan Media Pembelajaran Berbasis Android pada Materi Kelarutan untuk Meningkatkan Performa Akademik Peserta Didik SMA
}

\author{
Resti Yektyastuti $^{1 *}$, Jaslin Ikhsan ${ }^{2}$ \\ 12 Program Studi Pendidikan Sains, Program Pascasarjana, Universitas Negeri Yogyakarta \\ Jalan Colombo No. 1, Karangmalang, Yogyakarta 55281, Indonesia \\ * Korespondensi Penulis. Email: restiyektyastuti@yahoo.com
}

\begin{abstract}
Abstrak
Penelitian ini bertujuan untuk (1) mengembangkan media pembelajaran kimia berbasis Android pada materi kelarutan; (2) menguji tingkat kelayakan media pembelajaran yang dikembangkan; serta (3) menguji pengaruh penggunaan media pembelajaran yang dikembangkan terhadap performa akademik peserta didik SMA. Penelitian ini merupakan Research and Development dengan mengadaptasi model Borg \& Gall yang dimodifikasi menjadi lima tahap, yaitu pengumpulan informasi, perencanaan produk, pengembangan produk, validasi produk, dan evaluasi produk. Hasil penelitian menunjukkan bahwa (1) software media pembelajaran kimia berbasis Android pada materi kelarutan telah tersusun dengan mendapat masukan dari validator, teman sejawat dan pendidik kimia; (2) media pembelajaran yang dikembangkan dinilai layak digunakan pada pembelajaran kimia ditinjau dari penilaian aspek materi dan aspek media; serta (3) penggunaan media pembelajaran kimia yang dikembangkan memberikan pengaruh pada peningkatan performa akademik peserta didik SMA.
\end{abstract}

Kata Kunci: media pembelajaran, motivasi belajar, hasil belajar, kimia, kelarutan.

\section{Developing Android-Based Instructional Media of Solubility to Improve Academic Performance of High School Students}

\begin{abstract}
This study aims to: (1) develop android-based chemistry instructional media on solubility; (2) proof the feasibility of the developed chemistry instructional media; and (3) proof the effect of using the developed instructional media to the high school students academic performance. This study is classified to research and development that adapted Borg \& Gall models modified into five steps: information collecting, product planning, product developing, product validation, and product evaluating. The results of this research are: (1) a software of android-based chemistry instructional media was developed; (2) the developed instructional media were appropriate for teaching, in terms of material and media aspects evaluation; and (3) using of the developed instructional media improved the high school students academic performance.
\end{abstract}

Keywords: instructional media, learning motivation, learning outcome, chemistry, solubility.

How to Cite; Yektyastuti, R., \& Ikhsan, J. (2016). Pengembangan media pembelajaran berbasis android pada materi kelarutan untuk meningkatkan performa akademik siswa SMA. Jurnal Inovasi Pendidikan IPA, 2(1), 8899. doi:http://dx.doi.org/10.21831/jipi.v2i1.10289

Permalink/DOI: http://dx.doi.org/10.21831/jipi.v2i1.10289 


\section{PENDAHULUAN}

Pembelajaran pada hakikatnya merupakan proses interaksi antara peserta didik dengan lingkungannya, sehingga terjadi perubahan perilaku ke arah yang lebih baik. Banyak faktor yang memengaruhinya proses interaksi, baik faktor internal yang datang dari dalam individu maupun faktor eksternal yang datang dari lingkungan. Tugas pendidik yang paling utama adalah mengkondisikan lingkungan agar menunjang terjadinya perubahan perilaku bagi peserta didik (Mulyasa, 2008, p. 100).

Pembelajaran kimia menekankan pada pemberian pengalaman belajar secara langsung melalui pengembangan keterampilan proses dan sikap ilmiah (Depdiknas, 2006). Pembelajaran kimia dapat terlaksana dengan baik dengan adanya interaksi pembelajaran yang menarik antara pendidik dan peserta didik. Keberhasilan dalam mencapai tujuan pembelajaran sangat dipengaruhi oleh beberapa faktor, seperti strategi pembelajaran, metode dan pendekatan pembelajaran, serta sumber belajar yang digunakan baik dalam bentuk buku, modul, lembar kerja, maupun media.

Penggunaan media dalam pembelajaran dapat membantu keterbatasan pendidik dalam menyampaikan informasi maupun keterbatasan jam pelajaran di kelas. Media berfungsi sebagai sumber informasi materi pembelajaran maupun sumber soal latihan. Kualitas pembelajaran juga dipengaruhi oleh perbedaan individu peserta didik, baik perbedaan gaya belajar, perbedaan kemampuan kognitif, perbedaan kecepatan belajar, maupun perbedaan latar belakang.

Media pembelajaran dapat dibuat dan dirancang sesuai dengan perkembangan teknologi saat ini. Media pembelajaran berbantuan teknologi dan informasi (TIK) dapat digunakan untuk menjadikan pembelajaran menjadi menarik dan memberikan dampak yang positif terhadap performa akademik berupa motivasi belajar dan hasil belajar peserta didik (Chuang, 2014, p. 1969). Penggunaan media pembelajaran berbantuan TIK dapat membuat pembelajaran kimia menjadi lebih efektif sebagaimana yang diungkapkan Diedren (Sutrisno, 2011, p. 253; Riyadi \& Pardjono, 2014 p.176). Penggunaan media pembelajaran berbantuan TIK juga dapat memfasilitasi pelaksanaan pembelajaran seperti yang diinginkan PP No 32 Tahun 2013 pasal 19 ayat (1) yang menyebutkan bahwa kegiatan pembelajaran pada satuan pendidikan diselenggarakan secara interaktif, inspiratif, menyenangkan, menantang, dan memotivasi peserta didik.

Salah satu media pembelajaran berbantuan TIK yang dapat digunakan berupa media pembelajaran yang dioperasikan pada perangkat smartphone dengan sistem operasi Android. Saat ini, sistem operasi Android merupakan sistem operasi yang paling populer dan banyak digunakan oleh masyarakat, khususnya di kalangan peserta didik SMA. Pengguna Android di Indonesia sampai Juni 2015 mencapai 65,9\% dari seluruh pengguna smartphone (StatCounter, 2015).

Penggunaan media pembelajaran berbasis Android merupakan salah satu penerapan gaya belajar abad ke 21 (Calimag et al., 2014, p. 90). Penggunaan media pembelajaran sejenis ini berpotensi untuk membantu meningkatkan performa akademik peserta didik berupa hasil belajar pada ranah kognitif (Chuang \& Chen, 2007, p. 27; Jabbour, 2014, p. 2) dan motivasi belajar peserta didik (Hess, 2014, p. 35; Calimag et al., 2014, p. 90). Li et al. (2010, p.171) menyebutkan implementasi pembelajaran menggunakan smartphone dan tablet dapat memberikan dampak positif terhadap dimensi kognitif, metakognitif, afektif, dan sosial budaya. Smartphone dan tablet memiliki kekuatan untuk mentransformasi pengalaman belajar. Media pembelajaran jenis ini memungkinkan peserta didik belajar tidak terbatas oleh waktu dan tempat dengan aplikasi yang menarik (Squire, 2009, p.70; Meister, 2011, p. 28).

Penelitian ini mengembangkan media pembelajaran berbasis perangkat dengan sistem operasi Android untuk materi kimia SMA, yaitu materi kelarutan. Materi kimia berisi konsep yang cukup sulit untuk dipahami peserta didik karena menyangkut reaksi kimia dan hitungan serta menyangkut konsep yang bersifat abstrak dan mikroskopik (Sunyono et al., 2009, p.9). Penguasaan materi kelarutan pada ujian nasional 2013 tidak terlalu tinggi, yaitu hanya mencapai $66,31 \%$ untuk skala nasional dan 67,13\% untuk skala D.I. Yogyakarta (Kemdikbud, 2013).

Penelitian dan pengembangan ini bertujuan untuk mengembangkan media pembelajaran kimia berbasis Android pada materi kelarutan, menguji kelayakan media pembelajaran yang dikembangkan, dan menguji pengaruh penggunaan media pembelajaran yang dikembangkan terhadap peningkatan performa akademik berupa motivasi belajar dan hasil belajar peserta didik SMA. 


\section{METODE}

Penelitian ini merupakan Research and Development yang berupaya menghasilkan produk dan menguji keefektifan produk (Sugiyono, 2010, p. 407). Model pengembangan yang digunakan pada penelitian ini merupakan adaptasi dari model Borg \& Gall (1983, pp. 589-594). Hasil adaptasi model tersebut meghasilkan lima tahapan pengembangan, yaitu (1) pengumpulan informasi, (2) perencanaan produk, (3) pengembangan produk, (4) validasi produk, dan (5) evaluasi produk.

\section{Waktu dan Tempat Penelitian}

Penelitian ini dilakukan di SMAN 10 Yogyakarta untuk semua tahap evaluasi, yaitu uji coba perorangan, uji coba terbatas, dan uji coba lapangan. Penelitian dilaksanakan pada bulan Mei hingga Juni 2015.

\section{Subjek Penelitian}

Subjek penelitian terdiri atas subjek validasi media dan subjek uji coba. Subjek validasi media meliputi satu orang ahli materi dan satu orang ahli media, 5 orang peer reviewer, dan 5 orang pendidik kimia SMA. Uji coba produk terdiri atas uji coba perorangan, uji coba terbatas, dan uji coba lapangan. Subjek uji coba perorangan terdiri atas 9 peserta didik SMA kelas XI IPA, sedangkan subjek uji coba terbatas meliputi 30 peserta didik SMA kelas XI IPA. Subjek uji coba lapangan merupakan peserta didik SMA kelas XI IPA dengan rincian 32 peserta didik pada kelas eksperimen dan 31 peserta didik pada kelas kontrol.

\section{Prosedur Penelitian}

Penelitian ini dilakukan dengan 5 langkah hasil adaptasi model pengembangan Borg \& Gall (1983, pp. 589-594). Langkah yang dilakukan dalam penelitian ini, yaitu (1) pengumpulan informasi (studi literatur, survei lapangan, analisis kebutuhan, analisis kurikulum), (2) perencanaan produk (membuat flowchart, storyboard, naskah materi, soal evaluasi, serta mengumpulkan gambar, suara, dan musik), (3) pengembangan produk, (4) validasi produk (ahli materi, ahli media, peer reviewer, dan pendidik kimia), dan (5) evaluasi produk (uji coba perorangan, uji coba terbatas, uji coba lapangan). Performa akademik peserta didik yang menjadi bahasan pada penelitian ini dibatasi pada motivasi belajar dan hasil belajar kognitif peserta didik.

\section{Teknik dan Instrumen Pengumpulan Data}

Pengumpulan data pada penelitian ini menggunakan instrumen validasi media dan instrumen uji coba. Instrumen validasi media terdiri atas (1) lembar validasi media untuk ahli media pembelajaran, (2) lembar validasi materi untuk ahli materi, serta (3) lembar penilaian kualitas media untuk peer reviewer dan pendidik kimia. Instrumen uji coba terdiri atas (1) lembar penilaian kualitas media pembelajaran oleh peserta didik (digunakan pada uji coba perorangan dan uji coba terbatas), (2) angket motivasi belajar (digunakan pada uji lapangan), dan (3) soal tes hasil belajar kognitif (digunakan pada uji lapangan). Instrumen validasi dan instrumen penilaian kualitas media diadaptasi dari Nasir et al. (2012, pp. 576-579) dan Anggraeni \& Kustijono (2013, pp. 14-15).

Seluruh instrumen divalidasi oleh ahli (expert judgment) secara konstruk dan konten. Instrumen tes hasil belajar kognitif berupa soal pilihan ganda divalidasi oleh ahli dan juga divalidasi secara empirik.

Uji coba lapangan dilakukan untuk mengetahui pengaruh penggunaan media pembelajaran yang dikembangkan terhadap performa akademik peserta didik. Desain uji coba yang digunakan berupa Pretest-Posttest Control Group Design (Wiersma \& Jurs, 2009, p. 146)

\section{Teknik Analisis Data}

Kelayakan media untuk digunakan dalam pembelajaran dianalisis dari kategori kualitas media. Media dinilai layak jika memperoleh minimal kategori kualitas baik. Kategori kualitas media diperoleh dari data validasi media dan penilaian kualitas media pada tahap uji coba perorangan dan uji coba terbatas. Data penilaian kualitas media berupa data kuantitatif dengan skala 1-5. Data ini dianalisis dengan dihitung rata-rata skor untuk setiap aspek penilaian. Skor rata-rata dibandingkan dengan kategori kualitas media (Widoyoko, 2011, p. 238) seperti disajikan pada Tabel 1.

Tabel 1. Konversi Kualitas Media

\begin{tabular}{ccc}
\hline No & Rentang Skor & Kategori \\
\hline 1. & $\overline{\mathrm{X}}>\overline{\mathrm{X}} i+1,8 \mathrm{SB}_{\mathrm{i}}$ & Sangat baik (SB) \\
2. & $\overline{\mathrm{X}} i+0,6 \mathrm{SB}_{\mathrm{i}}<\overline{\mathrm{X}} \leq \overline{\mathrm{X}} i+1,8$ & Baik (B) \\
3. & $\mathrm{SB}_{\mathrm{i}}-\overline{\mathrm{X}} i-0,6 \mathrm{SB}_{\mathrm{i}}<\overline{\mathrm{X}} \leq \overline{\mathrm{X}} i+0,6$ & Cukup (C) \\
& $\mathrm{SB}_{\mathrm{i}}$ & \\
4. & $\overline{\mathrm{X}} i-1,8 \mathrm{SB}_{\mathrm{i}}<\overline{\mathrm{X}} \leq \overline{\mathrm{X}} i-0,6$ & Kurang (K) \\
& $\mathrm{SB}_{\mathrm{i}}$ & Sangat kurang \\
5. & $\overline{\mathrm{X}} \mathrm{i} \leq \overline{\mathrm{X}} i-1,8 \mathrm{SB}_{\mathrm{i}}$ & (SK) \\
\hline
\end{tabular}


Data performa akademik berupa data peningkatan motivasi belajar dan hasil belajar kognitif peserta didik. Data yang diperoleh melalui angket motivasi berupa data kualitatif dengan kategori SS (Sangat Setuju), S (Setuju), TS (Tidak Setuju), dan STS (Sangat Tidak Setuju). Data ini dikonversi menjadi data kuantitatif dengan ketentuan sesuai pada Tabel 2.

Tabel 2. Ketentuan Skor Angket Motivasi

\begin{tabular}{|c|c|c|c|}
\hline \multirow[b]{2}{*}{ No } & \multirow[b]{2}{*}{ Kategori } & \multicolumn{2}{|c|}{ Skor } \\
\hline & & $\begin{array}{l}\text { Pernyataan } \\
\text { Negatif }\end{array}$ & $\begin{array}{c}\text { Pernyataan } \\
\text { Positif }\end{array}$ \\
\hline 1. & $\begin{array}{l}\text { Sangat Tidak } \\
\text { Setuju (STS) }\end{array}$ & 5 & 1 \\
\hline 2. & Tidak Setuju (S) & 4 & 2 \\
\hline 3. & Ragu-ragu (R) & 3 & 3 \\
\hline 4. & Setuju (S) & 2 & 4 \\
\hline 5. & $\begin{array}{l}\text { Sangat Setuju } \\
\text { (SS) }\end{array}$ & 1 & 5 \\
\hline
\end{tabular}

Skor yang diperoleh dikonversi menjadi nilai menggunakan persamaan sebagai berikut.

$$
\text { Nilai }=\frac{\text { skor yang diperoleh }}{\text { skor maksimal }} \times 100
$$

Data hasil belajar kognitif diperoleh dari skor tes hasil belajar kognitif dalam bentuk 20 soal pilihan ganda beralasan. Skor tes berada pada rentang 0-100. Analisis validitas dan reliabilitas instrumen tes secara empirik dilakukan dengan program QUEST.

Motivasi belajar dan hasil belajar kognitif peserta didik diukur pada awal pembelajaran melalui pretest dan di akhir pembelajaran melalui posttest. Peningkatan (gain) motivasi belajar maupun hasil belajar kognitif dihitung menggunakan persamaan Hake (Hake, 1998, p.65).

$$
g=\frac{\mathrm{S}_{\mathrm{f}}-\mathrm{S}_{\mathrm{i}}}{100-\mathrm{S}_{\mathrm{i}}}
$$

Keterangan:

$g$ = gain (peningkatan),

$\mathrm{S}_{\mathrm{f}}=$ final test $($ skor posttest),

$\mathrm{S}_{\mathrm{i}}=$ initial test (skor pretest).

Signifikansi perbedaan peningkatan motivasi belajar dan hasil belajar kognitif dianalisis dengan menggunakan uji statistik multivariat (MANOVA). Uji MANOVA dapat dilakukan setelah prasyarat normalitas dan homogenitas data gain terpenuhi.

Uji normalitas data dilakukan untuk mengetahui normalitas distribusi dengan mengikuti pola kurva normal atau tidak. Uji normalitas dilakukan dengan menghitung nilai jarak Mahalonobis tiap kelompok uji dan memban- dingkannya dengan nilai chi-square (Stevens, 2009, pp. 106-108; Rencher, 1998, pp. 22-23). Apabila masing-masing kelompok memiliki nilai jarak Mahalonobis yang kurang dari chi square $\left(\chi^{2}\right)$ sebanyak $40-60 \%$, maka data berdistribusi secara normal.

Uji homogenitas data dilakukan untuk mengetahui sampel berasal dari populasi yang homogen atau tidak. Uji homogenitas dilakukan dengan uji Box's $M$. Pada taraf kepercayaan 95\%, matriks varian-kovarian dikatakan homogen apabila nilai signifikansi lebih besar dari nilai $\alpha(0,05)$.

\section{HASIL DAN PEMBAHASAN}

Pengembangan media pembelajaran kimia berbasis Android pada penelitian ini mengadaptasi model pengembangan Borg \& Gall (1983, pp. 589-594) dengan mengelompokkan tahapan pengembangan pada lima bagian utama, yaitu pengumpulan informasi, perencanaan produk, pengembangan produk, validasi produk, dan evaluasi produk.

Pengumpulan informasi dilaksanakan untuk memperoleh data sebagai langkah awal pengembangan. Pengumpulan informasi terdiri atas studi literatur, survei lapangan, analisis kebutuhan, dan analisis kurikulum. Berdasarkan hasil studi literatur diketahui bahwa peningkatan performa akademik, khususnya motivasi belajar dan hasil belajar kognitif peserta didik, dapat dibantu dengan penggunaan media pembelajaran yang menarik dan mendukung pembelajaran. Media pembelajaran dapat dirancang sesuai perkembangan teknologi informasi terbaru agar menjadi menarik dan memudahkan pendidik dan peserta didik dalam mengakses materi pembelajaran.

Hasil studi literatur menunjukkan bahwa teknologi informasi yang sangat luas digunakan berupa telepon genggam pintar (smartphone). Smartphone yang banyak digunakan merupakan smartphone dengan sistem operasi Android. Data dari Stat Counter Global Stats 2015 menempatkan Android pada peringkat pertama dalam penggunaan sistem operasi smartphone dan tablet dengan pengguna lebih dari 50\% dari total pengguna smartphone per April 2015. Smartphone Android juga banyak digunakan dalam mendukung pembelajaran di sekolah.

Survei lapangan dilakukan dengan observasi dan wawancara di SMA Negeri 10 Yogyakarta. Pembelajaran kimia di sekolah ini dilakukan sebagian besar menggunakan metode ceramah dan latihan soal. Pada materi tertentu, 
pendidik juga menggunakan presentasi power point untuk menjelaskan materi pembelajaran. Peserta didik tidak diwajibkan memiliki buku pegangan tentang materi kimia. Proses pembelajaran di sekolah ini sering melibatkan smartphone sebagai sumber belajar di kelas. Sebagian besar pendidik dan peserta didik memiliki smartphone. Smartphone khususnya Android digunakan sebagai sumber informasi tambahan jika informasi yang diinginkan tidak ditemukan di buku atau sumber belajar lain di sekolah.

Analisis kebutuhan dilakukan berdasarkan hasil survei lapangan. Berdasarkan hasil survei lapangan, dirumuskan bahwa pada pembelajaran kimia di sekolah, dapat ditunjang dengan media pembelajaran berbasis Android. Media jenis ini diharapkan dapat memudahkan peserta didik dalam belajar, meningkatkan motivasi belajar, serta membantu meningkatkan hasil belajar peserta didik terutama pada ranah kognitif. Media pembelajaran tersebut dapat memuat penjelasan materi dan disertai dengan evaluasi yang dikemas dalam bentuk permainan.

Materi yang dimuat dalam media berupa materi tentang kelarutan dan hasil kali kelarutan $\left(K_{\mathrm{sp}}\right)$. Materi ini dipilih karena penerapannya dekat dengan kehidupan sehari-hari. Materi ini membutuhkan pemahaman konsep dan perhitungan kimia yang baik. Media pembelajaran berisi penjelasan materi dan latihan soal yang bersifat interaktif sangat baik untuk menunjang proses pembelajaran pada materi kelarutan dan hasil kali kelarutan $\left(K_{s p}\right)$.

Analisis kurikulum dilakukan dengan melakukan identifikasi Standar Kompetensi (SK) dan Kompetensi Dasar (KD) untuk materi kelarutan dan hasil kali kelarutan $\left(K_{\mathrm{sp}}\right)$ sesuai dengan kurikulum 2006. Materi kelarutan dan hasil kali kelarutan $\left(K_{\mathrm{sp}}\right)$ diberikan kepada peserta didik SMA kelas XI semester genap. Materi ini diberikan untuk memenuhi Standar Kompetensi 4, yaitu memahami sifat larutan asam-basa, metode pengukuran dan terapannya. Kompetensi Dasar yang dituntut untuk dikuasai oleh peserta didik berupa Kompetensi Dasar 4.6, yaitu memprediksi terbentuknya endapan dari suatu reaksi berdasarkan prinsip kelarutan dan hasil kali kelarutan. Berdasarkan SK/KD ini ditentukan indikator dalam pengembangan media pembelajaran.

Perencanaan produk dilakukan dengan membuat rancangan produk dalam bentuk flowchart dan storyboard. Flowchart menggambarkan alur navigasi dalam mengoperasikan media pembelajaran pada perangkat Android. Story- board merupakan visual script yang dijadikan garis besar dalam pembuatan media pembelajaran. Storyboard menggambarkan secara rinci penataan gambar, tulisan, efek, animasi, suara, dan komponen lain pada tampilan layar media pembelajaran. Tahap perencanaan produk juga dilakukan pembuatan komponen produk berupa naskah materi, soal, gambar, suara, musik, dan kode pemrograman. Naskah materi dan soal disusun dari berbagai sumber yang relevan. Gambar yang mendukung penjelasan materi diunduh dan dikumpulkan dari berbagai sumber, begitu juga dengan suara dan musik yang digunakan. Kode pemrograman dirancang untuk memperoleh satu kesatuan aplikasi Android sesuai dengan maksud pengembangan.

Pengembangan produk media pembelajaran kimia dilakukan dengan menggunakan software Adobe Flash Professional CS 6 dengan Action Script 3. Keluaran produk berupa file berekstensi apk yang dapat dibuka pada perangkat Android yang sesuai dan kemudian secara otomatis akan menginstalasi media pembelajaran pada perangkat Android tersebut.

\section{Produk Hasil Pengembangan}

Produk hasil pengembangan berupa media pembelajaran kimia materi kelarutan yang dapat dioperasikan pada perangkat Android. Secara garis besar, menu yang terdapat pada media pembelajaran meliputi (1) petunjuk, (2) kompetensi, (3) materi, (4) evaluasi, (5) peringkat, dan (6) tentang (berisi profil pengembang).

Tampilan menu utama dapat dilihat pada Gambar 1. Pada bagian kanan atas menu utama terdapat 2 tombol yang berfungsi untuk mengatur musik selama media pembelajaran dioperasikan. Kedua tombol ini terus muncul pada setiap tampilan media pembelajaran untuk memudahkan pengguna dalam pengaturan suara. Tombol di sebelah kiri berupa tombol untuk menghentikan sementara (pause) musik dan tombol di sebelah kanan berupa tombol untuk menghentikan musik. Tombol untuk memulai kembali musik muncul setelah salah satu tombol ini dipilih.

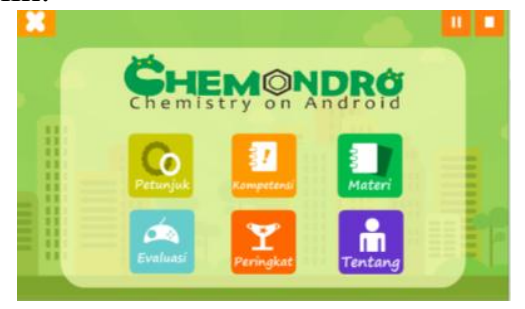

Gambar 1. Tampilan Menu Utama 
Menu petunjuk berisi keterangan singkat mengenai fungsi tombol yang ada pada media pembelajaran. Menu ini diposisikan pada urutan pertama di antara menu yang lain dengan maksud agar pengguna terlebih dahulu membaca petunjuk agar selanjutnya mudah dalam penggunaan media. Tampilan menu petunjuk dapat dilihat pada Gambar 2. Tombol menu yang terdapat pada bagian kiri atas tampilan berfungsi untuk kembali ke menu utama.

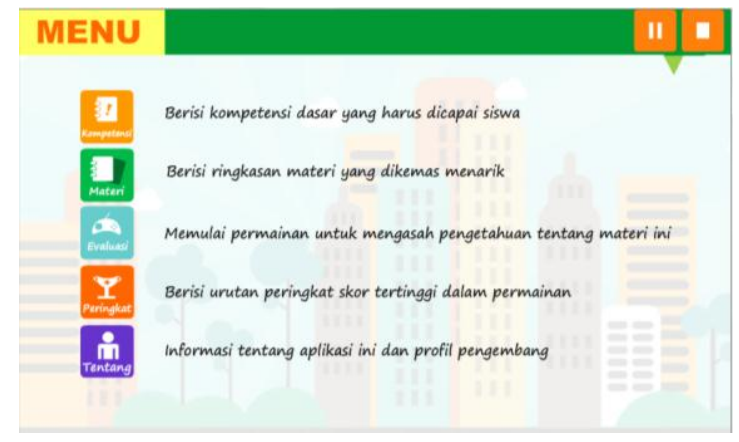

Gambar 2. Tampilan Menu Petunjuk

Menu kompetensi berisi keterangan mengenai Standar Kompetensi, Kompetensi Dasar, dan Indikator Pembelajaran yang menjadi acuan dalam pengembangan media pembelajaran. Tampilan menu kompetensi dapat dilihat pada Gambar 3.

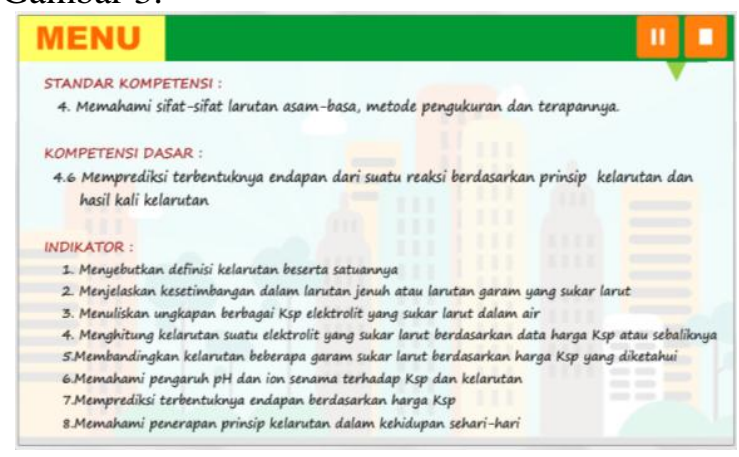

Gambar 3. Tampilan Menu Kompetensi

Menu materi berisi uraian materi kelarutan dan hasil kali kelarutan $\left(K_{\mathrm{sp}}\right)$ yang disajikan secara ringkas dengan disertai tambahan gambar yang mendukung penjelasan materi. Uraian materi secara umum dibagi ke dalam beberapa bagian, yaitu (1) kelarutan; (2) hasil kali kelarutan $\left(K_{\mathrm{sp}}\right)$; (3) faktor yang memengaruhi kelarutan; (4) reaksi pengendapan; serta (5) penerapan prinsip kelarutan dalam kehidupan sehari-hari. Materi disajikan dengan konsep seperti buku digital. Salah satu tampilan materi pada media pembelajaran dapat dilihat pada Gambar 4.

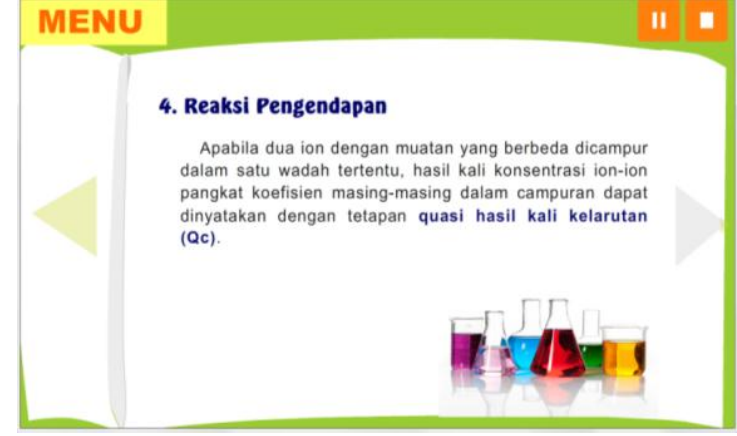

Gambar 4. Salah Satu Tampilan Menu Materi

Menu evaluasi berisi latihan soal yang dikemas dalam bentuk permainan petualangan. Permainan terdiri atas 5 level dengan tingkat kesulitan mudah ke sulit. Level awal terlebih dahulu harus dilewati untuk mencapai level di atasnya. Sebelum permainan dimulai, terdapat animasi cerita yang memotivasi pengguna untuk belajar. Selanjutnya pengguna harus $\log$ in dengan memasukkan nama dan memilih tokoh yang digunakan dalam permainan. Setiap set permainan diberikan 10 nyawa (10 kesempatan salah). Setiap pertanyaan yang dijawab salah akan mengurangi 1 nyawa. Permainan tidak dapat dilanjutkan jika nyawa pengguna habis. Beberapa soal dalam permainan berupa soal bonus yang dapat menambah nyawa pengguna. Soal dalam setiap level permainan keluar secara acak dari bank soal yang disediakan. Permainan terdiri atas 5 level dengan tingkat kesulitan mudah ke sukar.

Permainan pada level 1 berupa kuis benar-salah. Pengguna akan disuguhkan 10 pernyataan yang harus diidentifikasi ke dalam pernyataan benar atau salah. Tampilan permainan pada level 1 dapat dilihat pada Gambar 5. Umpan balik jawaban pengguna dan pembahasan soal muncul setelah pengguna menjawab masing-masing pertanyaan.

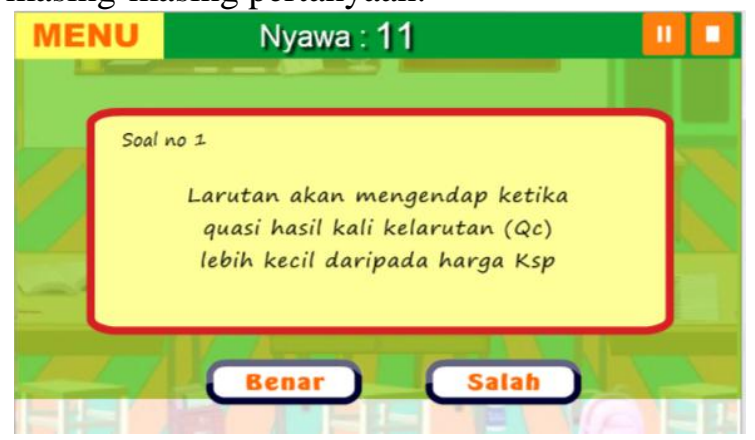

Gambar 5. Tampilan Permainan Level 1

Permainan pada level 2 berupa puzzle. Pengguna harus mengisi bagian yang kosong pada pertanyaan dengan potongan puzzle yang 
sesuai. Potongan puzzle disediakan di bagian bawah pertanyaan. Tampilan salah satu jenis puzzle pada level ini dapat dilihat pada Gambar 6.

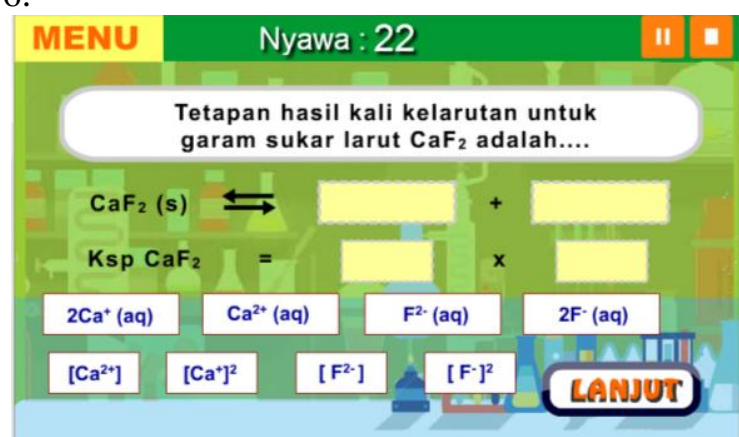

Gambar 6. Tampilan Permainan Level 2

Permainan pada level 3 merupakan permainan mencari kata yang berhubungan dengan materi kelarutan pada kotak yang berisi huruf yang tersusun secara acak. Tampilan permainan pada level 3 dapat dilihat pada Gambar 7.

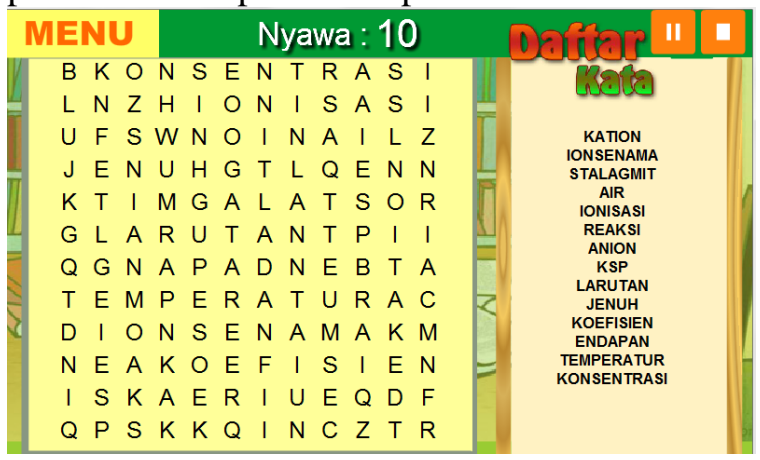

\section{Gambar 7. Tampilan Permainan Level 3}

Permainan pada level 4 berupa teka teki silang. Pertanyaan pada teka teki silang seluruhnya berhubungan dengan materi kelarutan. Tampilan permainan teka teki silang pada level 4 dapat dilihat pada Gambar 8 .

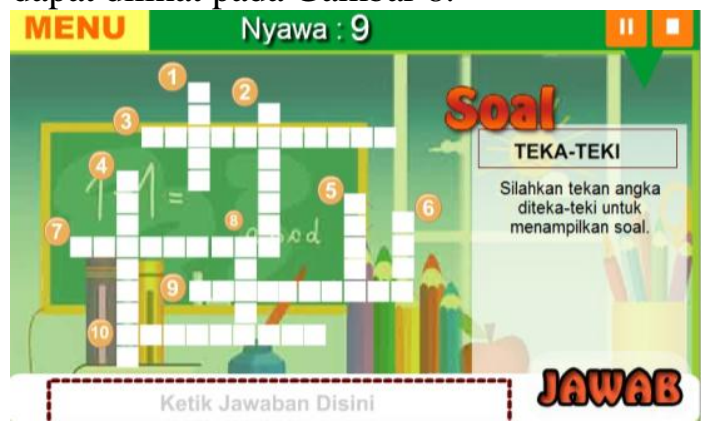

Gambar 8. Tampilan Permainan Level 4
Level 5 merupakan level terakhir. Permaian pada level ini berupa olimpiade kimia yang berisi pertanyaan pilihan ganda untuk materi kelarutan. Tampilan permainan pada level terakhir ini dapat dilihat pada Gambar 9.

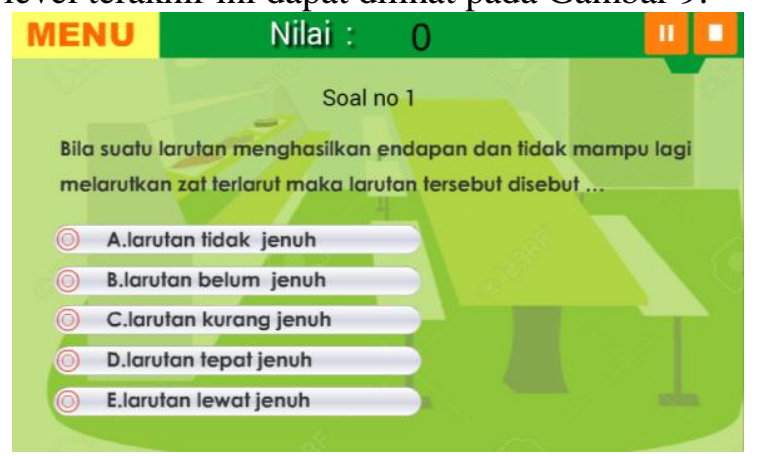

Gambar 9. Tampilan Permainan Level 5

Selain tampilan menu petunjuk, kompetensi, materi, dan evaluasi, juga terdapat menu peringkat dan menu tentang. Menu Peringkat berisi catatan tentang pencapaian pengguna. Nama dan skor yang diperoleh pengguna akan muncul dengan urutan skor tinggi ke rendah. Nama yang muncul sesuai dengan nama pengguna saat $\log$ in di awal permainan. Menu Tentang berisi keterangan media pembelajaran dan profil singkat pengembang. Pada menu ini juga terdapat link korespondensi yang ditujukan kepada pengembang. Link yang diberikan terkait email dan jejaring sosial milik pengembang.

\section{Validasi Produk}

Validasi produk dilakukan oleh seorang ahli materi, seorang ahli media, 5 peer reviewer, dan 5 pendidik kimia SMA. Validasi produk dilakukan dengan menggunakan instrumen penilaian media yang sudah divalidasi oleh validator instrumen penelitian secara konten dan kontruk.

\section{Validasi Aspek Materi}

Aspek materi pada media pembelajaran yang dikembangkan yang dinilai pada tahap validasi terdiri atas aspek pembelajaran dan aspek materi pembelajaran yang disajikan. Hasil penilaian aspek materi dapat dilihat pada Tabel 3. 
Jurnal Inovasi Pendidikan IPA, 2 (1), 2016 - 95

Resti Yektyastuti, Jaslin Ikhsan

Tabel 3. Hasil Penilaian terhadap Aspek Materi Pembelajaran

\begin{tabular}{|c|c|c|c|c|c|c|c|c|c|c|c|c|c|}
\hline \multirow{2}{*}{ No } & \multirow{2}{*}{ Aspek } & \multirow{2}{*}{$\begin{array}{c}\text { Ahli } \\
\text { Materi }\end{array}$} & \multicolumn{5}{|c|}{ Peer Reviewer } & \multicolumn{5}{|c|}{ Pendidik kimia } & \multirow{2}{*}{$\begin{array}{c}\text { Skor } \\
\text { Maksimal }\end{array}$} \\
\hline & & & I & II & III & IV & $\mathbf{V}$ & I & II & III & IV & $\mathbf{V}$ & \\
\hline 1. & Pembelajaran & 25 & 25 & 21 & 23 & 22 & 23 & 23 & 24 & 23 & 24 & 23 & 25 \\
\hline 2. & Materi & 41 & 41 & 37 & 40 & 40 & 38 & 42 & 40 & 37 & 40 & 38 & 45 \\
\hline & Jumlah & 66 & 66 & 58 & 63 & 62 & 61 & 65 & 64 & 60 & 64 & 61 & 70 \\
\hline & $\begin{array}{l}\text { Rata-rata } \\
\text { Kategori }\end{array}$ & \multicolumn{11}{|c|}{$62,73(89,61 \%)$} & 70 \\
\hline
\end{tabular}

Tabel 4. Hasil Penilaian terhadap Aspek Media Pembelajaran

\begin{tabular}{|c|c|c|c|c|c|c|c|c|c|c|c|c|c|}
\hline \multirow{2}{*}{ No } & \multirow{2}{*}{ Aspek } & \multirow{2}{*}{$\begin{array}{c}\text { Ahli } \\
\text { Media }\end{array}$} & \multicolumn{5}{|c|}{ Peer Reviewer } & \multicolumn{5}{|c|}{ Pendidik kimia } & \multirow{2}{*}{$\begin{array}{c}\text { Skor } \\
\text { Maksimal }\end{array}$} \\
\hline & & & I & II & III & IV & V & I & II & III & IV & V & \\
\hline 1. & Audio Visual & 45 & 47 & 45 & 46 & 44 & 47 & 50 & 47 & 51 & 48 & 47 & 55 \\
\hline & $\begin{array}{l}\text { Rekayasa Perangkat } \\
\text { Lunak }\end{array}$ & 21 & 23 & 23 & 22 & 23 & 22 & 22 & 21 & 24 & 23 & 23 & 25 \\
\hline & $\begin{array}{c}\text { Jumlah } \\
\text { ata-rata Keseluruhan } \\
\text { Kategori }\end{array}$ & \multicolumn{11}{|c|}{$\begin{array}{c}68,54(85,67 \%) \\
\text { Sangat Baik (SB) }\end{array}$} & $\begin{array}{l}80 \\
80\end{array}$ \\
\hline
\end{tabular}

Berdasarkan penilaian ahli materi, peer reviewer, dan pendidik kimia SMA/MA diperoleh skor rata-rata keseluruhan pada aspek materi pembelajaran, yaitu 62,73 atau $89,61 \%$ dari skor maksimal 70. Hasil konversi skor rata-rata menunjukkan bahwa media termasuk dalam kategori kualitas sangat baik (SB).

\section{Validasi Aspek Media}

Aspek media dinilai berdasarkan aspek tampilan audio visual dan aspek rekayasa perangkat lunak. Hasil penilaian aspek media dapat dilihat pada Tabel 4.

Skor rata-rata keseluruhan aspek media pembelajaran berdasarkan penilaian ahli media, peer reviewer, dan pendidik kimia SMA/MA adalah 68,54 atau $85,67 \%$ dari skor maksimal 80. Skor ini berada pada kategori kualitas sangat baik (SB).

Berdasarkan hasil validasi ini, media dinyatakan layak digunakan pada tahap uji coba. Selain mendapatkan penilaian kualitas, pada tahap ini juga diperoleh saran dan masukan untuk perbaikan produk media pembelajaran sebelum digunakan pada tahap uji coba. Saran dan masukan digunakan sebagai dasar revisi media pembelajaran.

\section{Evaluasi Produk}

Evaluasi produk dilakukan dalam tiga tahap, yaitu (1) uji coba perorangan; (2) uji coba terbatas; dan (3) uji coba lapangan. Seluruh subjek pada tahap evaluasi produk merupakan peserta didik SMA kelas XI IPA. Uji coba perorangan bertujuan untuk memperoleh penilaian kualitas produk berdasarkan penilaian dari peserta didik pada skala kecil. Uji coba terbatas juga dilakukan untuk memperoleh penilaian kualitas media berdasarkan penilaian peserta didik pada skala lebih besar. Pengaruh penggunaan produk dan efektivitasnya disimpulkan dari hasil uji coba lapangan.

\section{Uji Coba Perorangan dan Uji Coba Terbatas}

Uji coba perorangan dilakukan untuk mengetahui kualitas produk berdasarkan penilaian dari peserta didik. Uji coba ini juga dilakukan untuk mengetahui kekurangan dan kelemahan produk dari aspek pembelajaran dan tampilan produk serta untuk memperoleh tanggapan dan saran yang digunakan sebagai dasar pertimbangan revisi produk.

Peserta didik yang terlibat pada uji coba ini meliputi 9 orang peserta didik SMA kelas XI IPA yang terdiri atas 3 orang peserta didik dengan kemampuan akademik di bawah ratarata, 3 orang dengan kemampuan akademik ratarata, dan 3 orang dengan kemampuan akademik yang di atas rata-rata.

Uji coba terbatas dilakukan untuk memperoleh kriteria kualitas produk media pembelajaran berdasarkan penilaian peserta didik pada kelompok besar. Penilaian diberikan oleh 30 orang peserta didik dengan kemampuan akademik yang beragam. Penilaian dilakukan terhadap produk media pembelajaran yang telah direvisi berdasarkan saran dan tanggapan dari peserta didik pada tahap uji coba perorangan.

Uji coba terbatas menggunakan instrumen penilaian yang sama seperti pada uji coba perorangan. Aspek yang dinilai berupa aspek pembelajaran dan materi, serta aspek tampilan dan 
operasional media. Hasil penilaian pada tahap uji coba perorangan dan uji coba terbatas dapat dilihat pada Tabel 5.

Hasil penilaian terhadap media pada tahap uji coba produk diperoleh rata-rata skor keseluruhan sebesar 58,72 atau 78,29 \% dari skor maksimal 75. Hasil penilaian ini menunjukkan bahwa media pembelajaran kimia berbasis Android berada pada kategori kualitas baik (B).

Selain mendapatkan penilaian kualitas, pada tahap ini juga diperoleh saran dan masukan untuk perbaikan produk media pembelajaran sebelum digunakan pada tahap uji coba lapangan. Saran dan masukan digunakan sebagai dasar untuk melakukan revisi tahap akhir terhadap media pembelajaran.

Berdasarkan hasil uji coba produk media pembelajaran kimia berbasis android pada materi kelarutan yang telah dikembangkan dapat dinyatakan layak untuk digunakan dalam pembelajaran.

\section{Uji Coba Lapangan}

Uji coba lapangan dilaksanakan untuk mengetahui pengaruh penggunaan media pembelajaran yang dikembangkan terhadap peningkatan motivasi belajar dan hasil belajar kognitif peserta didik. Media pembelajaran yang digunakan pada uji coba ini berupa media pembelajaran yang telah direvisi berdasarkan saran dan masukan yang diperoleh dari tahap uji coba sebelumnya. Pembelajaran di kelas dilaksanakan berdasarkan rencana pelaksanaan pembelajaran (RPP) yang telah dirancang untuk kelas kontrol dan kelas eksperimen.

Pelaksanaan pembelajaran di kelas kontrol dan kelas eksperimen dilaksanakan dengan jumlah pertemuan yang sama banyak, materi yang sama, pendidik yang sama, dan bentuk evaluasi yang sama. Pembelajaran di kelas kontrol menggunakan media power point, sedangkan pembelajaran di kelas eksperimen menggunakan media power point dan pemberian media pembelajaran berbasis Android yang telah dikembangkan dan telah diujicobakan pada tahap sebelumnya.

Peningkatan motivasi belajar dan hasil belajar kognitif dilihat berdasarkan perbedaan nilai motivasi belajar dan hasil belajar kognitif pada saat pretest dan posttest. Pretest diberikan di awal pembelajaran pada pertemuan pertama di kelas dengan meminta peserta didik mengisi angket motivasi dan menyelesaikan tes kognitif yang diberikan. Posttest diberikan pada pertemuan akhir pada pembelajaran di kelas. Angket motivasi dan tes kognitif yang digunakan sama dengan angket dan tes yang digunakan pada pretest.

Soal pada tes hasil belajar kognitif terlebih dahulu telah divalidasi secara konten dan konstruk oleh validator instrumen dan telah divalidasi secara empiris pada peserta didik SMA yang telah menyelesaikan pembelajaran pada materi yang terdapat pada tes. Analisis hasil validasi empiris soal tes dilakukan dengan bantuan program QUEST. Hasil validasi terhadap 30 soal, diperoleh 26 butir soal yang dinyatakan valid dan dapat diterima dengan in fit Mean Squared (INFIT MNSQ) sebesar 1,01 dan Reliability of estimate sebesar 0,70. Hasil analisis ini sesuai dengan pendapat Subali (2012, p. 117) bahwa item atau testi/case/person dinyatakan fit dalam program QUEST apabila nilai INFIT MNSQ berada pada kisaran 0,77 sampai 1,30 . Soal yang digunakan dalam uji keefektifan sebanyak 20 soal.

Uji lapangan dilaksanakan di SMA Negeri 10 Yogyakarta. Kelas XI IPA 1 yang terdiri atas 31 peserta didik digunakan sebagai kelas kontrol dan keals XI IPA 4 yang terdiri atas 32 peserta didik digunakan sebagai kelas eksperimen. Rata-rata peningkatan hasil belajar kognitif di kelas kontrol dan kelas eksperimen dapat dilihat pada Tabel 6 .

Tabel 5. Hasil Uji Coba Perorangan dan Uji Coba Terbatas

\begin{tabular}{|c|c|c|c|c|}
\hline \multirow{2}{*}{ No } & \multirow{2}{*}{ Aspek } & \multicolumn{2}{|c|}{ Skor Rata-rata Uji Coba } & \multirow[t]{2}{*}{ Skor Maksima } \\
\hline & & Perorangan & Terbata: & \\
\hline 1. & Pembelajaran dan Materi & 19,00 & 21,20 & 25 \\
\hline 2. & Tampilan dan Operasional Media & 37,11 & 40,13 & 50 \\
\hline & Jumlah & 56,11 & 61,33 & 75 \\
\hline & Rata-rata keseluruhan & \multicolumn{2}{|c|}{$58,72(78,29 \%)$} & 75 \\
\hline & Kategori & & Baik ( & \\
\hline
\end{tabular}


Jurnal Inovasi Pendidikan IPA, 2 (1), 2016 - 97

Resti Yektyastuti, Jaslin Ikhsan

Tabel 6. Rata-rata Nilai Hasil Belajar Kognitif

\begin{tabular}{|c|c|c|c|c|c|c|c|c|}
\hline \multirow[b]{2}{*}{ No } & \multirow[b]{2}{*}{ Kelas } & \multirow{2}{*}{$\begin{array}{c}\text { Jumlah } \\
\text { Peserta } \\
\text { didik } \\
\end{array}$} & \multicolumn{2}{|c|}{ Pretest } & \multicolumn{2}{|c|}{ Posttest } & \multirow[b]{2}{*}{$\langle\mathrm{g}\rangle$} & \multirow[b]{2}{*}{ Kategori } \\
\hline & & & $\begin{array}{c}\text { Nilai } \\
\text { Rata-rata }\end{array}$ & $\begin{array}{c}\text { Ketuntasan } \\
(\%)\end{array}$ & $\begin{array}{c}\text { Nilai } \\
\text { Rata-rata }\end{array}$ & $\begin{array}{c}\text { Ketuntasan } \\
(\%)\end{array}$ & & \\
\hline 1. & Eksperimen & 32 & 49,562 & 0,031 & 85,813 & 90,625 & 0,725 & Tinggi \\
\hline 2. & Kontrol & 31 & 49,613 & 0 & 80,226 & 80,645 & 0,631 & Sedang \\
\hline
\end{tabular}

Tabel 7. Data Motivasi Belajar Peserta Didik

\begin{tabular}{|c|c|c|c|c|c|c|c|c|}
\hline \multirow{2}{*}{ No } & \multirow{2}{*}{ Kelas } & \multirow{2}{*}{$\begin{array}{c}\text { Jumlah Peserta } \\
\text { didik }\end{array}$} & \multicolumn{2}{|c|}{$\begin{array}{c}\text { Sebelum } \\
\text { Pembelajaran }\end{array}$} & \multicolumn{2}{|c|}{$\begin{array}{c}\text { Setelah } \\
\text { Pembelajaran }\end{array}$} & \multirow{2}{*}{$\langle\mathbf{g}\rangle$} & \multirow{2}{*}{ Kategori } \\
\hline & & & $\begin{array}{l}\text { Skor Rata- } \\
\text { rata }\end{array}$ & Nilai & $\begin{array}{c}\text { Skor Rata- } \\
\text { rata }\end{array}$ & Nilai & & \\
\hline 1. & Eksperimen & 32 & 108,313 & 72,208 & 122,313 & 81,542 & 0,336 & Sedang \\
\hline 2. & Kontrol & 31 & 110,67 & 73,758 & 119,323 & 79,548 & 0,220 & Rendah \\
\hline
\end{tabular}

Peningkatan motivasi dilihat dari perbedaan nilai motivasi sebelum dan setelah pembelajaran. Rekapan perolehan nilai motivasi secara lengkap dapat dilihat pada Tabel 7.

Pengaruh penggunaan media pembelajaran dapat dilihat dari hasil analisis statistik dengan analisis multivariat (MANOVA). Uji statistik dilakukan dengan bantuan program SPSS. Data yang digunakan pada uji MANOVA berupa data nilai gain pada masing-masing variabel terikat yang meliputi motivasi belajar dan hasil belajar kognitif.

Data nilai gain pada masing-masing kelas kontrol dan keals eksperimen dapat dianalisis dengan MANOVA jika memenuhi asumsi yang diperlukan. Asumsi uji MANOVA yang harus dipenuhi berupa normalitas dan homogenitas data.

\section{Normalitas}

Uji normalitas dilakukan untuk menentukan normalitas distribusi data di kedua kelompok uji. Uji normalitas dilakukan dengan bantuan program SPSS. Nilai Mahalonobis hasil perhitungan dengan program SPSS pada masing-masing kelas dapat dilihat pada Tabel 8.

Tabel 8. Analisis Normalitas Multivariat

\begin{tabular}{cccc}
\hline No & Kelas & $\begin{array}{c}\text { Persentase } \\
d_{i}^{2} \leq \chi_{\operatorname{mas}}^{2}\end{array}$ & Kesimpulan \\
\hline 1. & Eksperimen & 46,875 & $\begin{array}{c}\text { Berdistribusi } \\
\text { Normal }\end{array}$ \\
2. & Kontrol & 45,161 & $\begin{array}{c}\text { Berdistribusi } \\
\text { Normal }\end{array}$ \\
\hline
\end{tabular}

Berdasarkan data pada Tabel 8 dapat diketahui bahwa nilai Mahalonobis kurang dari atau sama dengan nilai chi squared $\left(\mathrm{d}_{\mathrm{i}}^{2} \leq\right.$ $\left.\chi_{\mathrm{p}, 0.5}^{2}\right)$ yang berada pada rentang $40-60 \%$, sehingga dapat disimpulkan bahwa data terdistribusi normal.

\section{Homogenitas}

Uji homogenitas dilaukan untuk mengetahui kesamaan matriks varian-kovarians variabel terikat secara bersamaan. Uji homogenitas dilakukan dengan bantuan program SPSS. Nilai gain pada kedua kelompok dapat dikatakan memiliki kesamaan matriks varian-kovarian jika nilai signifikansi uji Box's- $M$ lebih besar dari 0,05. Hasil uji homogenitas dapat dilihat pada Tabel 9.

Tabel 9. Hasil Perhitungan Uji Homogenitas

\begin{tabular}{ccc}
\hline Effect & Signifikansi & Kesimpulan \\
\hline Box's $M$ & 0,053 & Data Homogen \\
\hline
\end{tabular}

Hasil uji Box's $M$ diperoleh nilai signifikansi lebih besar dari 0,050 ( $p>0,050)$, sehingga dapat diambil kesimpulan bahwa matriks varians-kovarians dari populasi adalah sama atau homogen.

Hipotesis diuji melalui analisis MANOVA dengan bantuan program SPSS. Data yang digunakan berupa data yang berdistribusi normal dan bersifat homogen. Hipotesis yang diuji yaitu:

Ho: Tidak terdapat perbedaan peningkatan motivasi belajar dan peningkatan hasil belajar kognitif peserta didik kelas eksperimen dengan kelas kontrol.

Ha: Terdapat perbedaan peningkatan motivasi belajar dan peningkatan hasil belajar kognitif antara peserta didik kelas eksperimen dengan kelas kontrol.

Ho diterima atau ditolak didasarkan pada interpretasi besarnya nilai signifikansi hasil uji MANOVA dari hasil perhitungan dengan program SPSS. Apabila nilai signifikansi lebih kecil dari 0,05, maka Ho ditolak dan Ha dite- 
rima. Hasil analisis uji Manova dapat dilihat pada Tabel 10.

Tabel 10. Hasil Analisis Manova

\begin{tabular}{ccc}
\hline Effect & Signifikansi & Keterangan \\
\hline $\begin{array}{c}\text { Hotelling's } \\
\text { Trace }\end{array}$ & 0,000 & Ho ditolak \\
\hline
\end{tabular}

Berdasarkan hasil analisis MANOVA pada Tabel 10 terlihat bahwa nilai signifikansi kurang dari 0,050, sehingga dapat disimpulkan bahwa terdapat perbedaan peningkatan motivasi belajar dan hasil belajar kognitif peserta didik kelas kontrol dan kelas eksperimen.

\section{Pembahasan}

Media pembelajaran kimia berbasis Android yang berfungsi untuk meningkatkan performa akademik telah berhasil dikembangkan dengan menggunakan program komputer Adobe Flash Professional CS 6. Produk media pembelajaran yang dihasilkan berupa file dalam format android package (apk). File dalam format apk merupakan file syarat instalasi aplikasi pada perangkat Android. Jika file ini dibuka pada perangkat Android, maka aplikasi media pembelajaran akan otomatis terinstal pada perangkat tersebut.

Produk media pembelajaran kimia berbasis Android memiliki beberapa karakteristik, yaitu: (1) produk berupa software yang dapat dioperasikan dengan menggunakan perangkat Android; (2) produk mendukung pembelajaran kimia SMA pada materi kelarutan dan hasil kali kelarutan; (3) media dapat digunakan di dalam maupun di luar pembelajaran kimia di sekolah; serta (4) produk menyajikan penjelasan materi, contoh soal, dan latihan soal dalam bentuk permainan yang bervariasi dan disajikan secara menarik dan interaktif.

Hasil validasi dan uji coba produk menunjukkan bahwa media layak digunakan dalam pembelajaran kimia SMA materi kelarutan. Hasil uji coba lapangan yang dilakukan terhadap 1 kelas eksperimen menunjukkan bahwa media pembelajaran memberikan pengaruh terhadap peningkatan performa akademik peserta didik SMA berupa motivasi belajar dan hasil belajar kognitif.

Hasil uji coba tersebut sejalan dengan yang diungkapkan oleh Matsuo et al. (2012, pp.34-49), Sakat et al. (2012, p. 874), Anggraeni \& Kustijono (2013, pp. 17-18), serta Jabbour (2014, pp. 1-3) bahwa media pembelajaran berbasis teknologi dapat meningkatkan motivasi belajar dan membuat pembelajaran menjadi lebih menarik dan menyenangkan serta dapat memberikan pengaruh pada peningkatan hasil belajar.

Media pembelajaran yang dikembangkan dapat meningkatkan motivasi belajar dan hasil belajar kognitif karena media dikembangkan sesuai dengan taraf berpikir peserta didik (Sudjana \& Rivai, 2011, p. 3). Taraf berpikir manusia mengikuti tahap perkembangan dimulai dari berpikir konkret menuju ke berpikir abstrak, dimulai dari berpikir sederhana menuju berpikir kompleks. Penggunaan media pembelajaran erat kaitannya dengan tahapan berpikir tersebut sebab melalui media pembelajaran, informasi yang bersifat abstrak dapat dikonkretkan, sedangkan informasi yang kompleks dapat disederhanakan.

\section{SIMPULAN DAN SARAN}

\section{Simpulan}

Kesimpulan penelitian ini meiputi (1) software media pembelajaran kimia berbasis Android pada materi kelarutan telah berhasil dikembangkan; (2) media pembelajaran yang dikembangkan dinilai layak digunakan pada pembelajaran kimia ditinjau dari penilaian aspek materi dan aspek media; serta (3) penggunaan media pembelajaran kimia berbasis Android memberikan pengaruh pada peningkatan performa akademik berupa motivasi belajar dan hasil belajar kognitif peserta didik SMA.

\section{Saran}

Produk media pembelajaran kimia berbasis Android pada materi kelarutan dinilai layak digunakan pada pembelajaran, sehingga disarankan pendidik kimia dan peserta didik untuk dapat memanfaatkannya sebagai alternatif media pembelajaran kimia materi kelarutan. Media serupa juga perlu dikembangkan dengan materi pembelajaran yang lain untuk menunjang pelaksanaan pembelajaran di sekolah.

\section{DAFTAR PUSTAKA}

Anggraeni, R \& Kustijono, R. (2013). Pengembangan media animasi fisika pada materi cahaya dengan aplikasi flash berbasis android. Jurnal Pendidikan Fisika dan Aplikasinya (JPFA), 3 (1), 1118.

Borg, W. R., \& Gall, M. D. (1983). Educational research. New York: Longman.

Calimag, J. N., Mugel, P. A., Conde, R. S., \& Aquino, L. B. (2014). Ubquitous learning 
environment using android mobile application. International Journal of Research in Engineering \& Technology, 2 (2), 119-128.

Chuang, T. Y., \& Chen, W. F. (2007). Effect of digital games on children's cognitive achievement. Journal of Multimedia, 2 (5), 27-30.

Chuang, Y. T. (2014). Increasing learning motivation and student engagement through the technology-supported learning environment. Creative Education, 5, 1969-1978.

Depdiknas. (2006). Permendiknas Nomor 22 Tahun 2006 tentang standar isi satuan pendidikan dasar dan menengah.

Hake, R. R. (1998). Interactive-engagement versus traditional methods: A sixthousand-student survey of mechanics test data for introductory physics courses. American Journal of Physics Research, 66 (1), 64-74.

Hess, S. (2014). Digital media and student learning: impact of electronic books on motivation and achievement. New England Reading Associatiion Journal, 49 (2), 35-39.

Jabbour, K. K. (2014). An Analysis of the effect of mobile learning on lebanse higher education. Informatics in Education, 13 (1), 1-15.

Kemdikbud. (2013). Laporan hasil ujian nasional 2012/2013. Balitbang Kemdikbud.

Matsuo, K., Barolli, L., Xhafa, F., Koyama, A., $\&$ Durresi, A. (2008). New function for stimulating learners' motivation in a webbased e-learning system. Journal of Distance Education Technologies, 6 (4), 34-49.

Meister, J. (2011). 2011: The Year of the media tablet as a learning tool. Proquest, 65 (4), 28-31.

Mulyasa, E. (2008). Kurikulum berbasis kompetensi. Bandung: PT Remaja Rosdakarya Offset.
Rencher, A. C. (1998). Multivariate statistical inference and applications. New York: John Wiley \& Sons.

Riyadi, S., \& Pardjono, P. (2014). Pengembangan multimedia pembelajaran matematika berbasis komputer untuk kelas VIII SMP. Jurnal Inovasi Teknologi Pendidikan, 1(2). Retrieved fromhttp://journal.uny.ac.id/index.php/jit p/article/view/2527

Sakat, A. A., Mohd Zin, M. Z., Muhamad, R., Ahmad, A., Ahmad, N. A., \& Kamo, M. A. (2012). Educational technology media method in teaching and learning progress. American Journal of Applied Sciences, 9 (6), 874-888.

Squire, K. (2009). Mobile media learning: multiplicities of place. On the Horizon, 17 (1), 70-80.

StatCounter. (2015, Juli 2). Top 8 mobile \& tablet operating systems in indonesia from June 2013 to June 2015. Retrieved Juli 2, 2015, from http://gs.statcounter.com/\#mobile+tabletos-ID-monthly-201306-201506

Stevens, J. P. (2009). Applied multivariate statistics for the social sciences. New York: Taylor \& Francis Group.

Subali, B. (2012). Prinsip asesmen \& evaluasi pembelajaran. Yogyakarta: UNY Press.

Sugiyono. (2010). Metode penelitian pendidikan pendekatan kuantitatif, kualitatif, dan $R \& D$. Bandung: Alfabeta.

Sunyono, I. W. W., Susanto, E., \& Suyadi, G. (2009). Identifikasi masalah kesulitan dalam pembelajaran kimia sma kelas $\mathrm{x}$ di provinsi Lampung. Jurnal Pendidikan MIPA, 10 (2), 9-18.

Sutrisno. (2011). Pengantar pembelajaran inovatif. Jakarta: Gaung Perkasa Press.

Widoyoko, E. P. (2011). Evaluasi program pembelajaran. Yogyakarta: Pustaka Pelajar.

Wiersma, W., \& Jurs, S. (2009). Research methods in education, ninth edition. USA: Pearson Education, Inc. 